\title{
Caulerpin as a potential antiviral drug against herpes simplex virus type 1
}

\author{
Nathália Regina Porto Vieira Macedo, ${ }^{1,2}$ Michele S. Ribeiro, ${ }^{1,2}$ \\ Roberto C. Villaça, ${ }^{3}$ Wilton Ferreira, ${ }^{4}$ Ana Maria Pinto, ${ }^{1,2}$ \\ Valéria L. Teixeira, ${ }^{2,3,4}$ Claudio Cirne-Santos, ${ }^{1}$ Izabel C. N. P. \\ Paixão, ${ }^{* 1,2}$ Viveca Giongo ${ }^{1}$
}

${ }^{1}$ Laboratório de Virologia Molecular, Departamento de Biologia Celular e Molecular, Instituto de Biologia, Universidade Federal Fluminense, Brazil,

${ }^{2}$ Programa de Pós-graduação em Biologia das Interações, Universidade Federal Fluminense, Brazil,

${ }^{3}$ Departamento de Biologia Marinha, Instituto de Biologia, Universidade Federal Fluminense, Brazil,

${ }^{4}$ Programa de Pós-graduação em Química, Instituto de Química, Universidade Federal Fluminense, Brazil.

\begin{abstract}
About $80 \%$ of the human adult population is infected with HSV-1. Although there are many anti-HSV-1 drugs available (acyclovir, ganciclovir, valaciclovir, foscarnet), their continuous use promotes the selection of resistant strains, mainly in ACV patients. In addition to resistance, the drugs also have toxicity, particularly when administration is prolonged. The study of new molecules isolated from green algae with potential antiviral activity represents a good opportunity for the development of antiviral drugs. Caulerpin, the major product from the marine algae Caulerpa Lamouroux (Caulerpales), is known for its biological activities such as antioxidant, antifungal, acetylcholinesterase inhibitor (AChE) and antibacterial activity. In this work, we show that caulerpin could be an alternative to acyclovir as an anti-HSV-1 drug that inhibits the alpha and beta phases of the replication cycle.
\end{abstract}

Revista Brasileira de Farmacognosia Brazilian Journal of Pharmacognosy 22(4): 861-867, Jul./Aug. 2012

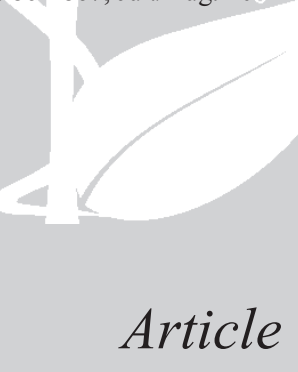

Article

Received 5 Dec 2011

Accepted 10 Feb 2012

Available online 29 May 2012

Keywords: Caulerpa caulerpin Herpes simplex type 1 cytotoxicity antiviral

ISSN 0102-695X http://dx.doi.org/10.1590/S0102695X2012005000072

\section{Introduction}

The type 1 herpes simplex viruses (HSV-1) are enveloped viruses containing double-stranded linear DNA belonging to the subfamily Alphaherpesvirinae (Gilbert et al., 2002). They are the primary cause of oral and facial lesions in humans, establishing lytic infection in mucocutaneous epithelial cells and latent infection in sensory ganglia (Placek \& Berger, 2010).

The lytic cycle of HSV-1 involves the expression of three viral gene sets: an immediate early (IE) or $\alpha$ phase, an initial (I) or $\beta$-phase and a late (L) or $\gamma$ phase (Hancock et al., 2006). In the alpha and beta phase are synthesized factors responsible for regulation of viral replication, antigenic presentation and genome replication, respectively, and in the gamma phase, the proteins that form the capsid (Whitley \& Roizman, 2001). After lytic infection and local replication in the mucosa, HSV-1 can reach nerve terminals and infect peripheral sensory neurons. The nucleocapsid moves through axonal transport to the trigemeal ganglia, where the viral genome is released and rapidly associated with histones to form episomal DNA (Knipe \& Cliffe, 2008). During latency, the viral transcription is restricted to Latency Associated
Transcripts (LAT) and some authors have suggested that LAT produce anti-apoptotic effects (Allen et al., 2011; Perng et al., 2000). In neuronal cells, LAT were shown to reduce viral gene expression and replication during productive infection (Mador et al., 1998).

About $80 \%$ of the human adult population is now infected, but mostly may not show clinical manifestations, which contributes for their its greater spread (Kelly et al., 2009). Diseases caused by HSV-1 infection appear frequently (Rozenberg et al., 2011). In children about 3 to 5 years old, clinical manifestations last 5 to 12 days (López Garcia et al., 2002). Bioinformatic analyses revealed a number of putative $\mathrm{TH}$ responsive elements (TRE) located in the critical regulatory regions of HSV-1 genes such as thymidine kinase (TK) latency associated transcript (LAT) (Hsia et al., 2011). In addition, infections caused by HSV-1 may be responsible for complications, especially in immunocompromised patients, leading in some cases to permanent injury, encephalitis, and even death death, depending on the severity of the case (Jones \& Isaacs, 2004).

Caulerpa Lamouroux is an exclusively marine and benthic genus of green algae (Caulerpales, Caulerpaceae). Caulerpa species are characterized 
by a stem divided into an upright portion (fronds) of various sizes and shapes and a prostrate portion with the rhizoids for attachment to the substrate. Due to this external differentiation with the formation of stolons, algae of the genus Caulerpa can colonize rocky and sandy substrates (Reviers, 2006). The species Caulerpa racemosa (Forsskål) J.Agardh is considered to be an alga with great invasive potential; in just seventeen years after the first report, it colonized twelve countries, as well as several islands in the Mediterranean Sea and Atlantic Ocean (Verlaque et al., 2000, 2004). In addition to the impacted areas, the genera is also found in native form in the southeast of Perth and Hopetown and was introduced in Adelaide in South Australia, where the waters are less impacted (Klein \& Verlaque, 2008).

Extracts of the alga C. racemosa obtained using solvents of different polarities are reported to exhibit various biological activities such as antioxidant (Cavas \& Yurdakoc, 2005, Chew et al. 2008, Matanjun et al., 2008), antifungal, acetylcholinesterase (AChE) inhibitor, antibacterial (Radwan et al., 2007), and antinociceptive activities (Souza et al., 2009). Moreover, they can reduce blood pressure and treat rheumatism (Novaczek, 2001).

Although there are few studies of this species, pharmacology has shown great interest in algae in recent years, mainly because of the secondary metabolites that are potentially useful for the development of new drugs for the treatment for human diseases caused by viruses, bacteria and fungi, as well as certain types of cancer and Alzheimer's (Smit, 2004, Wijesekara et al., 2011).

According to Rocha et al. (2007), caulerpin (1) is the major substance in the acetone extract of Brazilian C. racemosa. Caulerpin (1), a non-toxic red pigment, has a unique bisindole structure found in $80 \%$ of the species of Caulerpa (Vidal et al., 1984). However, this substance is not unique to Caulerpa, having also been isolated from the red alga Chondrus armatus (Harvey) Okamura. According to Rocha (2004), this finding reinforces the idea of a consortium of Caulerpa and bacterial biofilms, since the production of caulerpin requires the intervention of bacteria capable of making nitrogen available in the water column for the metabolism of these algae.

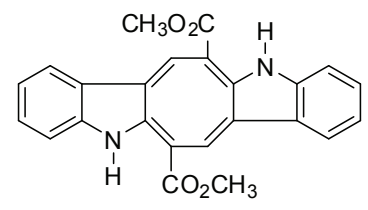

1

Because the drugs currently used to control infection by HSV-1 can cause side effects and strains resistant to these drugs have emerged, this work reports the antiviral activity of caulerpin. Earlier studies with Caulerpa had shown anti-HSV activity in sulphated polysaccharides from Caulerpa brachypus Harvey, $C$. okamurae Weber-van Bosse and C. scapelliformis (R. Brown ex Turner) C. Agardh (Lee et al., 2004). In this work, we analyze the anti-HSV-1 activity of caulerpin isolated from C. racemosa collected in the archipelago of São Pedro and São Paulo, a group of rocky islands located about $1000 \mathrm{~km}$ off the coast of Rio Grande do Norte.

\section{Materials and Methods}

The archipelago of São Pedro and São Paulo is situated at latitude $00^{\circ} 55^{\prime} \mathrm{N}$ and longitude $029^{\circ} 21^{\prime} \mathrm{W}$, lying about $600 \mathrm{~km}$ from the archipelago of Fernando de Noronha and about $1000 \mathrm{~km}$ from Cabo Calcanhar in Rio Grande do Norte, the nearest point on the continental Brazilian coast. Specimens of Caulerpa racemosa were collected in May of 2007 and 2008 by scuba diving in the sublittoral zone on the western side of the archipelago in the region called the "Caulerpa zone", at depths ranging from 50 to $10 \mathrm{~m}$. The seaweeds were washed with local sea water and separated from sediments, epiphytes and other associated organisms. The algae were collected and identified by one by us (RCV).

All solvents were HPLC grade. Analytical thin-layer chromatography (TLC) separations were carried out on Merck silica gel 60 F-254 (0.2 mm) precoated aluminum plates. Once developed, the plates were visualized by spraying with $2 \%$ ceric sulphate in sulfuric acid, followed by gentle heating. Silica gel 60 (Merck, 70-230 and 230-400 mesh) was used for column chromatography. Nuclear magnetic resonance (NMR) spectra were recorded in $\mathrm{CDCl}_{3}(100 \%$, Aldrich). After extraction with $\mathrm{CH}_{2} \mathrm{Cl}_{2}$ at room temperature, the material was filtered and the solvent was removed by using a rotary evaporator under reduced pressure. The extract was stored under refrigeration. The extract was subjected to thin layer chromatography with eluents of different polarities. Analyses by analytical thin layer chromatography (TLC) were performed on silica gel 60 F254 aluminum plates. The revelations of the chromatographic spots were made by inspection under UV light (at 254 and $366 \mathrm{~nm}$ ) and spraying with a solution of $2 \%$ ceric sulfate in sulfuric acid, followed by heating. The column chromatography was performed on silica gel 60 (70-230 mesh) and RP-18 (70-230 mesh).

Air-dried specimens (70 g) were extracted successively with $\mathrm{CH}_{2} \mathrm{Cl}_{2}$. Evaporation of the crude extract yielded $2.4 \mathrm{~g}$ of residue (about $3.3 \%$ of the dry mass) of which $1 \mathrm{~g}$ was subjected to purification by silica gel-column chromatography (elution with $n$-hexane, $\mathrm{CH}_{2} \mathrm{Cl}_{2}$ and EtOAc). The fractions eluted with $\mathrm{CH}_{2} \mathrm{Cl}_{2} /$ EtOAc (1:1) contained 1, obtained in pure form as orange-red needle-shaped crystals after re-crystallization from n-hexane. The identification of 1 as caulerpin was 
based on comparison of physical and spectroscopic data with literature data

\section{Cells and viruses}

Vero cells (African green monkey Cercopithecus aethiops kidney cells; ATCC, Hanassas, VA, USA) were cultured in Dulbecco's modified medium (DMEM) supplemented with $5 \%$ of fetal bovine serum (FBS; HyClone, Logan, UT, USA), 0.1 $\mu \mathrm{M}$ HEPES and 2.5 $\mu \mathrm{g} / \mathrm{mL}$ gentamycin at $37^{\circ} \mathrm{C}$ in $5 \% \mathrm{CO}_{2}$. Vero cells were subconfluent in all assays and were used prior to passage 20. The stock of HSV-1 was obtained with the strain HSV-1 (AR-29) (Lagrota et al., 2004; AndrighettiFröhner et al., 2005) at a multiplicity of infection (MOI) equal to 0.1 for $1 \mathrm{~h}$ at $37{ }^{\circ} \mathrm{C}$. Briefly, after the incubation, the monolayer was washed with phosphate-buffered saline (PBS) and cells were cultured for an additional 48 h. After this period, the cells were lysed by three cycles of freezing, centrifuged at $1500 \times g$ at $4{ }^{\circ} \mathrm{C}$ for $20 \mathrm{~min}$ to remove cellular debris, and the supernatants collected, titered by plaque assay and stored at $-70{ }^{\circ} \mathrm{C}$ for further studies.

\section{Cytotoxicity assay and selectivity index (SI)}

The HSV-1 KOS strain, susceptible to acyclovir (ACV), was diluted in DMEM without serum and multiplied in VERO cells, using a multiplicity of infection (MOI) of 0.1 (Lagrota et al., 1994; Esquenazi et al., 2002). After $24 \mathrm{~h}$ of infection, the cells were lysed by freezing and centrifuged at $400 \times g$ for $20 \mathrm{~min}$ at $4{ }^{\circ} \mathrm{C}$. The HSV-1 titer was determined by viral plaque reduction assay (Kuo et. al., 2001). Virus stocks were stored at -70 ${ }^{\circ} \mathrm{C}$ until use.

\section{Cytotoxicity assays}

To evaluate the cytotoxicity of caulerpin (1), we used the tetrazolium salt MTT [3-(4,5-dimethylthiazol-2yl)-2,5-diphenyl tetrazolium bromide] (Sigma), a watersoluble compound that has a yellow color in aqueous solution and is readily incorporated by viable cells, where it is reduced by dehydrogenases present in mitochondria. When reduced, MTT is converted into formazan, a purplecolored water-insoluble substance stored in the cytoplasm of the cell. The MTT cytotoxic assays was performed with Vero cells in 96-multiwell plates $\left(10^{5}\right.$ cells/well $)$ treated with different concentrations (50, 250,500 and $1000 \mu \mathrm{M}$ ) of caulerpin (1) at $37^{\circ} \mathrm{C}$ in an atmosphere of $5 \% \mathrm{CO}_{2}$ for $72 \mathrm{~h}$. After this, $50 \mu \mathrm{L}$ of a $1 \mathrm{mg} / \mathrm{mL}$ stock solution of MTT was added to each well. After incubation for $3 \mathrm{~h}$, each well received $50 \mu \mathrm{L}$ of acidic isopropanol $(0.04 \mathrm{~N} \mathrm{HCl}$ in isopropanol). The concentrations were determined in an automatic plate reader at $570 \mathrm{~nm}$ as the measurement wavelength and $690 \mathrm{~nm}$ as the reference wavelength (Mosmann, 1983; Denizot \& Lang, 1986). The 50\% cytotoxic concentration (CC50) was calculated from the experimental dose-response curves by linear regression analysis.

\section{Plaque reduction assay}

For the plaque assay, we infected monolayers of Vero cells $\left(10^{5}\right)$ in 24-well plates with HSV-1 (KOS strain) at an MOI equal to 1 for $1 \mathrm{~h}$ at $37^{\circ} \mathrm{C}$. Cells were washed with PBS to remove residual virus and the test substance was added diluted in DMEM with 2.5\% FBS. After $20 \mathrm{~h}$, cells were lysed and cellular debris was cleared by centrifugation. The virus titer was determined in Vero cells maintained in six well plates $\left(3 \times 10^{5}\right.$ cells/ well) and infected with different dilutions of HSV-1 for 1 $\mathrm{h}$ at $37{ }^{\circ} \mathrm{C}$ in an atmosphere of $5 \% \mathrm{CO}_{2}$. After this period, residual virus was removed and the monolayers were covered with DMEM with 5\% fetal bovine serum and 1\% methylcellulose. After $72 \mathrm{~h}$, cell monolayers were fixed with $10 \%$ formaldehyde and stained with $0.1 \%$ crystal violet. Then the viral titer was determined by the number of viral plaques $(\mathrm{PFU} / \mathrm{mL})$. For comparison, linear regression of the dose response curves for acyclovir (ACV) was also performed to calculate EC50 values.

\section{Time course infection}

In order to determine the inhibition of the replicative cycle of HSV-1 by caulerpin (1), Vero cells were cultured in six well plates $\left(3 \times 10^{5}\right.$ cells/well $)$ and separated into five groups (Gong et al., 2002). Adsorption: Vero cells were treated with $50 \mu \mathrm{M}$ of the compound for $2 \mathrm{~h}$ at $4{ }^{\circ} \mathrm{C}$. After washing, cells were infected with 100 $\mathrm{PFU} / \mathrm{mL}$ for $1 \mathrm{~h}$ at $37^{\circ} \mathrm{C}$ in an atmosphere of $5 \% \mathrm{CO}_{2}$. Penetration: Vero cells were infected with $100 \mathrm{PFU} / \mathrm{mL}$ at $4{ }^{\circ} \mathrm{C}$ for $1 \mathrm{~h}$, washed with glycine solution in $\mathrm{PBS}, \mathrm{pH}$ 2.2, and the temperature raised to $37^{\circ} \mathrm{C}$ for $1 \mathrm{~h} .0-3 \mathrm{~h}$ p.i.: Vero cells were infected with $100 \mathrm{PFU} / \mathrm{ml} \mathrm{HSV-1}$ for $1 \mathrm{~h}$ at $37{ }^{\circ} \mathrm{C}$ in an atmosphere of $5 \% \mathrm{CO}_{2}$. After this period (time 0$)$, the viral inoculum was removed and the cells were cultured with the test substance $(50 \mu \mathrm{M})$ for 3 h. 3-6 h p.i.: Vero cells were infected with $100 \mathrm{PFU} / \mathrm{ml} \mathrm{HSV-1}$ for $1 \mathrm{~h}$ at $37^{\circ} \mathrm{C}$ in an atmosphere of $5 \% \mathrm{CO}_{2}$. After $3 \mathrm{~h}$ p.i., the cells were treated with the substance, $6-20 \mathrm{~h}$ p.i.: Vero cells were infected with $100 \mathrm{PFU} / \mathrm{ml} \mathrm{HSV-1}$ for $1 \mathrm{~h}$ at $37^{\circ} \mathrm{C}$ in an atmosphere of $5 \% \mathrm{CO}_{2}$. At $6 h$ p.i. the cells were treated with $10 \mu \mathrm{M}$ test substance, which remained in contact with the cell. After each of these procedures, the monolayers were covered with DMEM with 5\% fetal bovine serum and $1 \%$ methylcellulose for $72 \mathrm{~h}$, fixed with $10 \%$ formaldehyde and stained with $0.1 \%$ crystal violet to determine the number of viral plaques. 


\section{Results and Discussion}

Tests of cell viability are important to determine the cytotoxicity of new substances in the early stages of drug development (Putnam et al., 2002). The equilibrium between the pharmacological and toxicological effects of a substance is an important requirement for its applicability as a future drug (Melo et al., 2000). In this experiment, we determined the concentrations of the substance that are able to kill $50 \%$ of Vero cells (CC50) and compared these values with those obtained with acyclovir, used as the positive control. The viability test performed in Vero cells showed that caulerpin is very promising as a potencial drug for human cells. The CC50 value of caulerpin (1) was even better than that of acyclovir (Table 1), reaching almost $18 \%$ of the reference value. These results encouraged us to continue the examine its anti-HSV-1 activity.

By definition, cytopathic effects (CPE) are irreversible modifications caused by viral replication in the host cells. For Vero cells submitted to HSV-1 replication, there is a loss of adherence and the cells acquire a round shape and bright appearance and are often linked to each other by cytoplasmic processes (Figure 1). Our results showed an EC50 value very similar to that of acyclovir. We cannot say at this time whether these substances act in the same stage of the replicative cycle. According to Rang et al. (2001) there are numerous mechanisms of action of antiviral drugs and those that are most employed in clinical use during the lytic cycle act on the viral polymerase in the adsorption and penetration phases (Rang et al., 2001, De Clercq, 2001, 2004). The discovery of acyclovir $\left(\right.$ Zovirax $^{\circledR}$ ) as a selective anti-herpes agent by Schaeffer and colleagues (Elion et al., 1977, Schaeffer et al., 1978) began a new era in antiviral chemotherapy in 1978. ACV is a nucleoside analogue with an incomplete guanine ribosyl lacking the hydroxyl groups at carbons $2^{\prime}$ and $3^{\prime}$. In its mechanism of action, it is phosphorylated by a viral thymidine kinase and subsequently is di-and tri-phosphorylated by celular enzymes. Finally, when it is captured by the viral DNA polymerase (complex UL30/ UL42), it results in disruption of the formation of the DNA strand due to the absence of the 3'-OH (Cheng et al., 1983, Coen, 1996; De Clercq, 2004). Our next step will be to study more thoroughly the action with the viral polymerase.

Based on the results obtained for cell viability and the antiviral inhibitory effect, it is possible to calculate the selectivity index (SI), which represents the degree of safety for the use of a compound. This pharmacological parameter was calculated from the ratio between the CC50 and the EC50 of the substance. For caulerpin (1), the S.I. value was higher than that of acyclovir (Table 1), showing that it is somewhat safer as an antiviral. Caulerpin (1) thus represents a possible candidate for further esting for anti-HSV-1 therapy in pre-clinical studies.

Table 1. Cell viability (CC50), antiviral effect (EC50) and selectivity index (S.I.) for caulerpin (1) in pre-clinical tests compared to acyclovir.

\begin{tabular}{lccc}
\hline Substance & CC50 $(\mu \mathrm{M})^{*}$ & EC50 $(\mu \mathrm{M})^{*}$ & S.I. $^{*}$ \\
\hline caulerpin & 1167 & 1,29 & 904 \\
acyclovir & 960 & 1,09 & 880 \\
\hline
\end{tabular}

*All assays were performed in triplicate with Vero cells according to methods described in the literature.

Another approach that permits a more detailed analysis of viral inhibition is accomplished through successive stages of disruption of the genes involved in the replicative cycle of HSV-1. The replicative cycle of herpes simplex virus results in the activation and regulation of three consecutive groups of genes: immediate, early and late, which express the alpha, beta and gamma proteins, respectively. Through changes in the temperature of incubation and different periods in the presence of the infected cells, we could verify the stage where caulerpin stops the viral replication, i.e., at the alpha, beta or gamma genes.

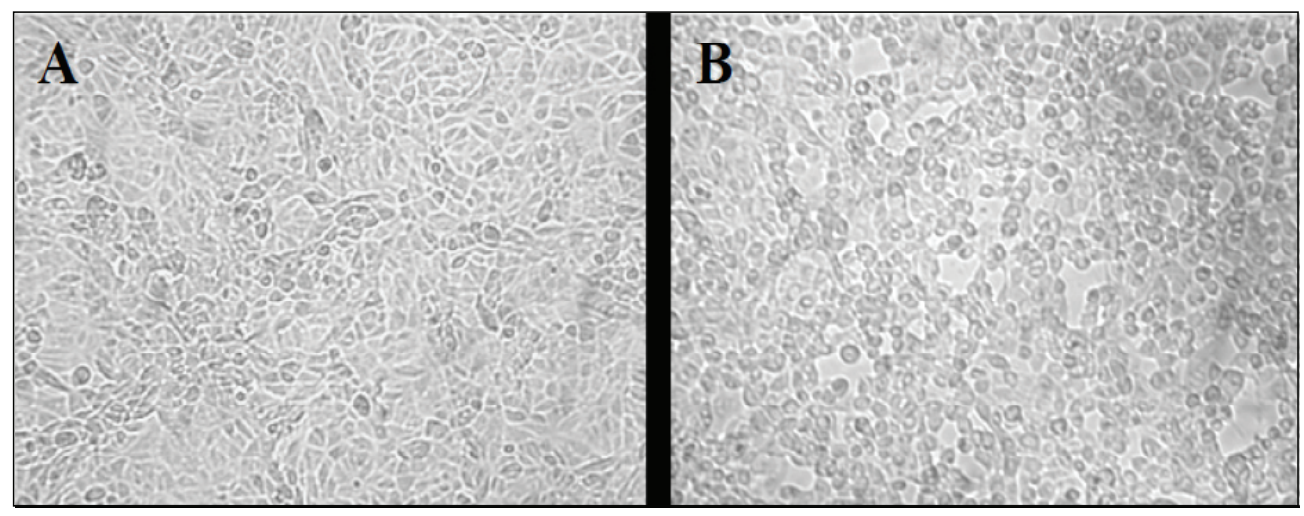

Figure 1. Representative photomicrographs of Vero cells with cytopathic effects after $72 \mathrm{~h}$ of infection with HSV-1. A. Control without treatment; B. Infected without treatment. 
The anti-HSV-1 activities of several compounds derived from brown algae have been reported. Abrantes et al. (2010) showed that 8,10,18-trihydroxy-2,6dolabelladiene and 6-hydroxydichotoma-4,14-diene1,17-dial inhibited HSV-1 replication in a dose-dependent manner, resulting in EC50 values of 5.10 and $5.90 \mu \mathrm{M}$, respectively. Our results showed that caulerpin (1) could partially inhibit the expression of the early and late genes of HSV-1 (Figure 2). The $\beta$-phase proteins include enzymes that are necessary for replication of the viral genome: DNA polymerase (complex UL30/ UL42); thymidine kinase (TK); binding protein of the single-stranded DNA (SSB), also known as ICP8; DNA helicase-primase; origin binding protein (UL9 protein); and those involved in nucleotide metabolism. The viral DNA replication stimulates the transcription of the late genes encoding structural proteins of the virion (Cliffe \& Knipe, 2008). The kinetics of gene expression end with the appearance of the proteins of the $\gamma$ phase, which are the structural proteins of the virion, including tegument and envelope and viral particle assembly proteins (Boehmer \& Lehman, 1997).

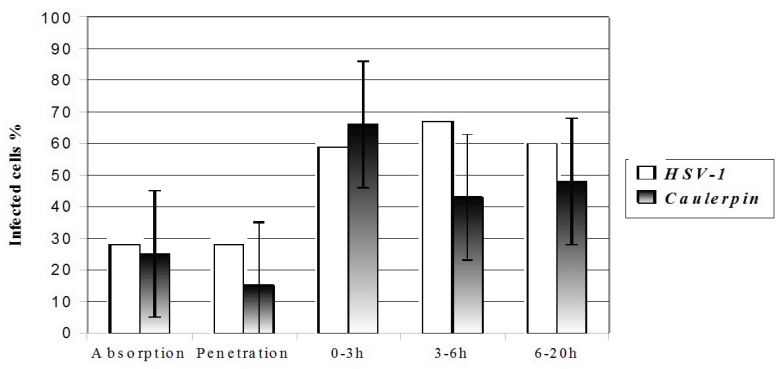

Figure 2. Time course of the infection of HSV-1 in the presence of caulerpin $(50 \mu \mathrm{M})$.

The reduction of $34 \%$ in the replication means that this inhibition is not complete, but we believe that the concentration of the substance may have been underestimated. Caulerpin (1) has no effect as a virucidal substance (data not shown), even at $4 \mathrm{~h}$ of incubation in systems without the presence of cells.

In conclusion, the study of new molecules isolated from green algae with potential antiviral activity appears to be a good opportunity for the development of antiviral drugs, especially for the $\alpha$ and $\gamma$ phases of the replication of HSV-1, which acyclovir is not able to inhibit. The development of new substances against these phases of the replication of $\mathrm{HSV}-1$ is of particular interest since there are currently no drugs available at the clinic stage that target these steps. Moreover, these steps are different from those inhibited by ACV. The current study clearly demonstrates that caulerpin (1) is a promising substance for anti-HSV-1 therapy. As a result, we are currently conducting additional toxicity and activity studies to determine the effectiveness of caulerpin in vivo.

\section{Acknowledgments}

The authors thank CNPq-Universal, CAPES, FOPESQ-UFF and FAPERJ for the financial support and fellowships. We are grateful to the CNPq for productivity fellowships to ICNPP and VLT.

\section{References}

Abrantes, J, Barbosa J, Cavalcanti D, Pereira RC, Fontes CFL, Teixeira VL, Souza TML, Paixão ICP 2010. The effects of the diterpenes isolated from the Brazilian brown algae Dictyota pfaffii and Dictyota menstrualis against the herpes simplex type-1 replicative cycle. Planta Med 76: 339-344.

Allen SJ, Mott KR, Wechsler SL, Flavell RA, Town T, Ghiasi H 2011. Adaptive and innate transforming growth factor beta signaling impact herpes simplex virus 1 latency and reactivation. J Virol 85: 11448-11456.

Andrighetti-Fröhner CR, Sincero TC, Silva AC, Savi LA, Gaido CM, Bettega JM, Mancini M, Almeida MT, Barbosa RA, Farias MR, Barardi CR, Simões CM 2005. Antiviral evaluation of plants from Brazilian Atlantic Tropical Forest. Fitoterapia 76: 374-378

Boehmer PE, Lehman IR 1997. Herpes simplex vírus DNA replication. Annu Rev Biochem 66: 347-384.

Cavas L, Yurdakoc K 2005. An investigation on the antioxidant status of the invasive alga Caulerpa racemosa var. cylindracea (Sonder) Verlaque, Huisman, et Boudouresque (Caulerpales, Chlorophyta). J Exp Mar Biol Ecol 325: 189-200.

ChengYC, Huang ES, Lin JC, Mar, EC, Pagano JS, Dutschman GE, Grill SP 1983 Unique spectrum of activity of 9-[(1,3-dihydroxy-2-propoxy)methyl]-guanine against herpesviruses in vitro and its mode of action against herpes simplex virus type 1. Proc Natl Acad Sci 80: 2767-2770.

Chew YL, Lim YY, Omar M, Khoo KS 2008. Antioxidant activity of edible brown, green and red seaweeds from the tropical region. LWT-Food Sci Thecnol 41: 10671072.

Coen DM 1996. Antiviral drug resistance in herpes simplex virus. Adv Exp Med Biol 394: 49-57.

De Clercq E 2001. Antiviral drugs: current state of the art. $J$ Clin Virol 22: 73-89.

De Clercq E 2004. Antiviral drugs in current clinical use. J Clin Virol 30: 115-133.

Denizot F, Lang R 1986. Rapid colorimetric assay for cell growth and survival. Modifications to the tetrazolium dye procedure giving improved sensitivity and reliability. J Immunol Methods 22: 271-277.

Elion GB, Furman PA, Fyfe JA, Miranda P, Beauchamp L, Schaeffer HJ 1977. Selectivity of action of an antiherpetic agent, 9-(2-hydroxyethoxymethyl) guanine; Proc Natl Acad Sci 74: 5716-5720. 
Esquenazi DE, Wigg MD, Miranda MFS, Rodrigues HM, Tostes BF, Rozental S, Silva JR, Alviano CS 2002. Antimicrobial and antiviral activities of polyphenolics from Cocos nucifera Linn. (Palmae) husk fiber extract. Res Microbiol 153: 647-652.

Gilbert C, Bestman-Smith J, Boivin G 2002. Resistance of herpesviruses to antiviral drugs: clinical impacts and molecular mechanisms. Drug Resist 5: 88-114.

Gong Y, Matthews B, Cheung D, Tam T, Gadawski I, Leung D, Holan G, Raff J, Sacks S 2002. Evidence of dual sites of action of dendrimers: SPL-2999 inhibits both virus entry and late stages of herpes simplex virus replication. Antivir Res 55: 319-329.

Hancock M H, Corcoran JA, Smiley JR 2006. Herpes simplex virus regulatory proteins VP16 and ICP0 counteract an innate intranuclear barrier to viral gene eExpression. Virology 352: 237-252.

Hsia SC, Gautam R, Balish D 2011. Effects of thyroid hormone on HSV-1 gene regulation: implications in the control of viral latency and reactivation. Cell Biosci 1: 24-24.

Jones CA, Isaacs D 2004. Management of Herpes Simplex Virus infections. Curr Paediatrics 14: 131-136.

Kelly NC, Zimet GD, Aalsma MC, Berstein DI, Fortenberry JD, Rosenthal SL 2009. Intent to accept and acceptance of herpes testing in adolescents and young adults. Sex Transm Infect 85: 296-299.

Klein J, Verlaque M 2008. The Caulerpa racemosa invasion: a critical review. Mar Pollut Bull 56: 205-225.

Knipe DM, Cliffe A 2008. Chromatin control of herpes simplex virus lytic and latent infection. Nature Rev Microbiol 6: 211-221.

Kuo YC, Chen CC, Tsai WJ, Ho YH 2001. Regulation of herpes simplex virus type 1 replication in Vero cells by Psychotria serpens: relationship to gene expression, DNA replication, and protein synthesis. Antiviral Res 51: 95-109.

Lagrota MHC, Wigg MD, Santos MMG, Miranda MMFS, Camara FP, Couceiro JNSS, Costa SS 1994. Inhibitory activity of extracts of Alternantera brasiliana (Amaranthaceae) against the herpes simplex virus. Phytother Res 8: 358-361.

Lee JB, Hayashi K, Maeda M, Hayashi T 2004 Antiherpetic activities of sulfated polysaccharides from green algae. Planta Med 70: 813-817.

López Garcia F, Ascarza RE, Martinez JCR, Pedreno AES 2002. Interferon therapy for herpes simplex virus infection in a 70 years old patient. An Med Interna 19: 600-601.

Mador N, Goldenberg D, Cohen O, Panet A, Steiner I 1998. Herpes simplex virus type 1 latency associated transcripts suppress viral replication and reduce immediate-early gene mRNA levels in a neuronal cell line. J Virol 72: 5067-5075.

Matanjun P, Mohamed S, Mustapha NM, Muhammad K, Ming $\mathrm{CH}$ 2008. Antioxidant activities and phenolics content of eight species of seaweeds from north Borneo. $J$ Appl
Phycol 20: 367-373.

Melo OS, Maria SS, Vidal BC, Haun M, Duran N 2000. Violacein cytotoxicity and induction of apoptosis in V79 cells. Cell Develop Biol Animal 36: 639-543.

Mosmann T 1983. Rapid colorimetric assay for cellular growth and survival: application to proliferation and cytotoxicity assays. J Immunol Methods 65: 55-63.

Novaczek I 2001. A guide to the common edible and medicinal sea plants of the Pacific Islands. Community Fisheries Training Pacific Series 3A, Supplementary Resource to Sea Plants: Pacific Series 3. Fiji: University of South Pacific/Secretariat of the Pacific Community.

Placek BJ, Berger SL 2010. Chromatin dynamics during herpes simplex virus-1 lytic infection Biochim Biophys Acta 1799: 223-227.

Perng GC 2000. Virus-induced neuronal apoptosis blocked by the herpes simplex virus latency associated transcript. Science 287: 1500-1503.

Putnam KP, Bombick DW, Doolittle DJ 2002 Evaluation of eight in vitro assays for assessing the cytotoxicity of cigarette smoke condensate. Toxicol In Vitro 16: 599607.

Radwan MAA, Ragab EA, Sabry NM, El-Shenawy SM 2007. Synthesis and biological evaluation of new 3 -substituted indole derivatives as potential anti-inflammatory and analgesic agents. Biol Med Chem 15: 3832-3841.

Rang HP, Dale MM, Ritter JM 2001. Farmacologia. Rio de Janeiro: Guanabara Koogan.

Reviers B de 2006. Biologia e filogenia das algas. Porto Alegre: Artmed.

Rocha FD 2004. Atividade antioxidante de produtos naturais de algas marinhas bentônicas e espécies de Bromeliacea. Rio de Janeiro, 423 p. Tese de Doutorado, Programa de Pós graduação Núcleo de Pesquisas em Produtos Naturais, Universidade Federal do Rio de Janeiro.

Rocha FD, Soares AR, Houghton PJ, Pereira RC, Kaplan MAC, Teixeira VL 2007. Potential cytotoxic activity of some Brazilian seaweeds on human melanoma cells. Phytother Res 21: 170-175.

Rozenberg F, Deback C, Agut H 2011. Herpes Simplex Encephalitis: from virus to therapy. Infect Disord Drug Targets 11: 235-250.

Schaeffer HJ, Beauchamps L, Miranda P, Elion GB 1978. 9-(2Hydroxyethoxymethyl) guanine activity against viruses of the herpes group. Nature 272: 583-585.

Smit AJ 2004. Medicinal and pharmaceutical uses of seaweed natural products: A review. J Appl Phycol 16: 245-262.

Souza MC 1999. Synthesis of novel nucleosides of 4-oxoquinoline-3-carboxylic acids. Anal Heteroatm Chem 10: 199-202.

Verlaque M, Boudouresque CF, Meinesz A, Gravez V 2000. The Caulerpa racemosa complex (Caulerpales, Ulvophyceae) in the Mediterranean Sea. Bot Mar 43: 49-68.

Verlaque M, Afonso-Carillo J, Gil-Rodríguez MC, Durand C, 
Boudouresque CF, Le Parco Y 2004. Blitzkrieg in a marine invasion: Caulerpa racemosa var. cylindracea (Bryopsidales, Chlorophyta) reaches the Canary Islands (north-east Atlantic). Biol Invasions 6: 269-281.

Vidal LM, Villaça R, Pereira RC 1984. Susceptibility of macroalgae to herbivorous fishes at Rocas Atoll, Brazil. Bot Mar 49: 379-385.

Wijesekara I, Pangestuti R, Kim S 2011. Biological activities and potential health benefits of sulfated polysaccharides derived from marine algae. Carbohyd Polym 84: 1421.
Whitley RJ, Roizman B 2001. Herpes Simplex Virus infections. The Lancet 357: 1513-1518.

\section{*Correspondence}

\section{Izabel Paixão}

Laboratório de Virologia Molecular, Departamento de Biologia Celular e Molecular, Universidade Federal Fluminense

Outeiro São João Baptista s/n, Campus Valonguinho, 24210130 Niteroi-RJ, Brazil ipaixao@vm.uff.br Tel. +552126292280 